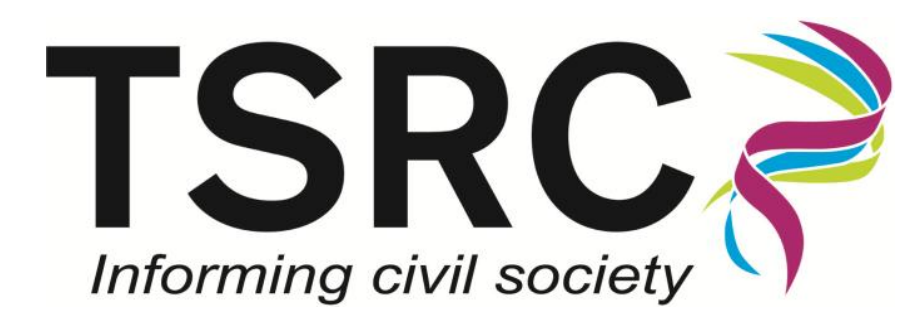

Third Sector Research Centre

Working Paper 99

\title{
Oil and water rarely mix: exploring the relative stability of nonprofit revenue mixes over time
}

Simon Teasdale*, Janelle Kerlin**, Dennis Young** and Jung In Soh**

June 2013

*Third Sector Research Centre, University of Birmingham, UK

${ }^{* *}$ Andrew Young School of Policy Studies, Georgia State University, Atlanta, GA, USA 


\section{Abstract}

This paper explores whether nonprofits are increasingly adopting mixed revenue strategies, and the sustainability of these strategies over time. We constructed a panel using NCCS (National Centre for Charitable Statistics) data from 1998 and 2007, and divided nonprofits into three groups: commercial, donative and mixed revenue. We found no evidence that nonprofits are increasingly adopting mixed revenue strategies. Mixed revenue strategies appeared less sustainable over time than predominately commercial or predominately donative strategies. Our results suggest that for most nonprofits, relying predominately on either commercial or donative revenue is a more stable equilibrium than attempting to achieve a balanced revenue mix. Exceptions may be those nonprofits, such as arts organisations, where there is a natural alliance between donors and customers.

\section{Keywords}

Hybridity, modern portfolio theory, nonprofit, revenue, sustainability.

\section{Acknowledgments}

This is the author original manuscript of a paper which has been accepted for publication in the Journal of Social Entrepreneurship. The full reference of the final versions is: Simon Teasdale, Janelle Kerlin, Dennis Young, and Jung In Soh Oil and Water Rarely Mix: Exploring the Relative Stability of Nonprofit Revenue Mixes Over Time, Journal of Social Entrepreneurship Vol. 4, Iss. 1, 2013, pp. 6997, http://www.tandfonline.com/doi/abs/10.1080/19420676.2012.762799. 


\section{Contents}

1. Introduction.

3

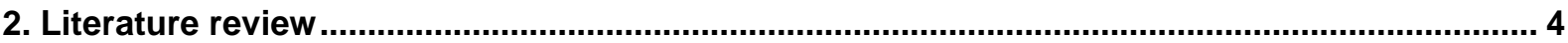

2.1 To what extent are nonprofits increasingly adopting mixed revenue strategies? ...................... 5

2.2 How stable are mixed revenue strategies over time? ....................................................... 5

2.3 Which organisations are adopting mixed revenue strategies? ........................................... 6

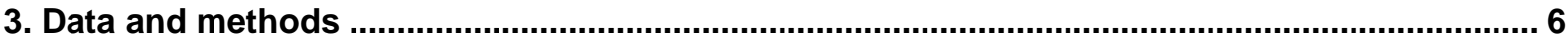

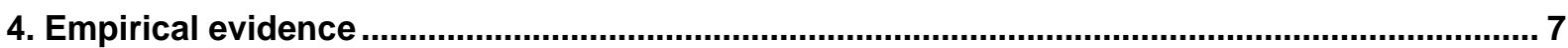

4.1 Characteristics of nonprofit revenue mixes in 1998..................................................... 7

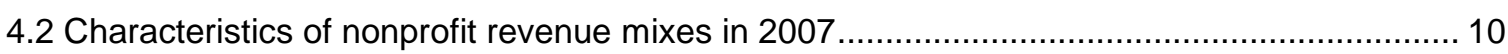

4.3 The relative stability of different revenue mixes over time …............................................ 11

4.4 Characteristics of stable mixed revenue nonprofits ............................................................... 16

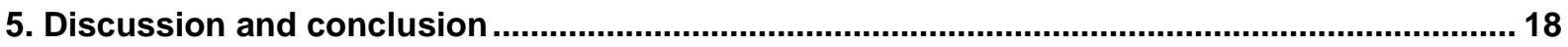

5.1 Implications for the future understanding of nonprofits' revenue mixes ................................ 19

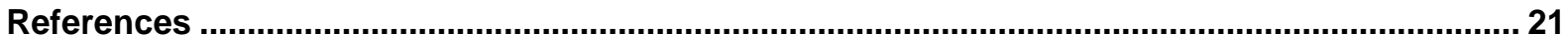




\section{Introduction}

The empirical study of organisations' changing revenue mixes is a comparatively underdeveloped area of nonprofit research. Hansmann (1987) distinguished between donative and commercial nonprofits on the basis of their primary sources of income (grants and donations or earned income). Although recognising that boundaries between these two ideal types were blurred, Hansmann saw no need to develop a third category of mixed revenue nonprofit, perhaps because these organisations were not, in his view, sufficiently numerous or theoretically distinct enough to warrant more than a passing mention.

However, since Hansmann's contribution, some attention has been paid in the literature to the emergence of mixed revenue forms of nonprofit which combine donative and commercial revenue (see for example Billis, 2010), in part as a response to arguments about resource dependency (Froelich, 1999) or the benefits of diversification (Carroll and Stater, 2009) and appeal to multiple stakeholder groups (Young, 2007). It would seem that mixed revenue nonprofits have become sufficiently numerous to now warrant a distinct stream of academic literature. But mixed revenue strategies may be difficult to sustain over time as organisations are pulled in different directions by competing goals and operational priorities associated with diverse sources of funds (Billis, 2010; Young et al., 2012). This raises questions as to whether nonprofits actually are adopting mixed revenue strategies, and if so, whether these strategies are sustainable over time.

In this article we investigate these questions by drawing upon National Centre for Charitable Statistics (NCCS) data collated between 1998 and 2007. The article proceeds as follow. In the next section we briefly review the literature on nonprofits' revenue mixes, paying particular attention to portfolio theory as applied to nonprofits. We then describe the characteristics of our data. In the empirical section we show that at the aggregate level the distribution of (commercial and donative) revenue within nonprofits in the United States (US) was virtually unchanged between 1998 and 2007. By constructing a matched sample containing all nonprofits for which we have observations in both 1998 and 2007, we are able to show that whereas commercial and donative nonprofits generally maintained (or even increased) their reliance on a single revenue source, just $28 \%$ of nonprofits which were mixed revenue in 1998 maintained this revenue mix in 2007. This is however more than would have occurred if the mixed revenue group were redistributed randomly in 2007 . We then explore the characteristics of those nonprofits which were mixed revenue in both 1998 and 2007. These consistent mixed revenue nonprofits tended to be smaller and showed lower growth across all revenue sources. They were particularly overrepresented in certain fields of activity that have special appeal to both paying customers and philanthropic donors, most notably in the arts. In the discussion section we attempt to explain our results, and suggest that portfolio theory may not be a sufficiently powerful lens through which to understand nonprofits' revenue mixes. Finally we highlight the limitations of our research and suggest how the dynamic study of nonprofits' revenue mixes might fruitfully be explored in the future. 


\section{Literature review}

In recent years considerable attention has been paid to the commercialisation of nonprofits and the development of mixed revenue streams. The general presumption is that nonprofits were previously more reliant on grants and donations and have diversified into commercial revenue as a response to resource dependence.

Alongside a substantial normative literature aimed at practitioners (see for example Dees et al., 2001) an evidence base is developing around the assumed benefits of revenue diversification. In a ground breaking article Froelich (1999) convincingly argued that nonprofits in the US were increasingly diversifying away from traditional donative sources of revenue as a response to increased competition for resources, and suggested that diversified revenue mixes may make them more stable over time. The logic behind this stability argument would seem impeccable. Numerous authors have drawn upon Markowitz's $(1952 ; 1959)$ theory of portfolio selection to explain why diversified revenue strategies can help nonprofits balance risk and reward. Markowitz shows how investors make trade-offs between risk and reward based on future expectations. A diversified selection of investments with low covariance reduces expected risk but also reduces the chances of maximising reward. That is by investing in a range of stocks across different industries the investor minimises the chances that the failure of a single stock (or industry) will dramatically reduce their portfolio. A concentrated portfolio of investments with high covariance increases risk because the failure of the single stock (or industry within which stocks are clustered) would dramatically reduce the value of the portfolio. However somebody considering themself an expert stock picker might choose to rely on this approach believing that they can beat the average market return.

It would initially appear reasonable to adapt portfolio theory to understand nonprofits' revenue diversification strategies. Nonprofits draw upon three main types of income: commercial revenue; grants and donations (donative revenue); and investment income (Yetman et al., 2009). ${ }^{1}$ These however, are very broad categories. For example, commercial revenue consists of sales of goods and services to government or end users, whether directly related to a nonprofits mission, or from unrelated subsidiary activities aimed at raising revenue to subsidise a nonprofits mission; and from membership fees where members receive a direct benefit from their subscriptions. Donative revenue consists of grants and donations, and may be derived from individuals or from organisations whether nonprofit, public or private (Kerlin and Pollak, 2011; Weisbrod, 1998). Commercial and donative revenue have relatively low covariance. Commercial revenue is more stable over time - that is it is less subject to large fluctuations (see Froelich, 1999; McKay et al., 2011) and may be less sensitive to the economic cycle than donative revenue. By deriving revenue from a range of commercial and donative sources it would be expected that nonprofits are better able to negotiate shocks such as the loss of a large government grant.

Certainly empirical evidence would appear to support the stability argument for a balanced revenue portfolio. Caroll and Stater (2009) show that diversifying away from donative revenue led to a reduction in overall revenue volatility. However, in common with most of the literature their approach is 
heavily parametric. Carroll and Stater (2009) drew upon the NCCS CORE dataset between 1991 and 2003 to directly model a measure of revenue volatility, based on percentage deviations from trend for each charity. They take a fixed-effects approach, also including lagged endogenous variables (relying on econometric techniques from a decade earlier, which encounter problems of bias described in Bond 2002 and Arellano 2003).

Markowitz's (1952) theory of portfolio selection would also suggest that if nonprofits are able to act as expert stock pickers and accurately predict which revenue sources will prove most valuable in the future then those which diversify less would be expected to grow more. There is some evidence to support this proposition. Kim and Bradach (2012) found that more than $90 \%$ of the 201 largest nonprofits formed between 1975 and 2008 concentrated their funding efforts rather than diversifying them. Similarly, a Bridgestone Group study found that the 144 nonprofits that reached at least \$50 million in annual revenue since their founding in 1970 used a single dominant funding source to grow (Foster and Fine, 2007).

\subsection{To what extent are nonprofits increasingly adopting mixed revenue strategies?}

Portfolio theory generally assumes a rational investor basing decisions upon future expectations. Given the preponderance of academic and practitioner orientated literature highlighting the benefits of diversifying into commercial revenue, one might expect that nonprofits are increasingly adopting mixed or commercial revenue strategies at the expense of donative revenue. Much of the literature highlights the stability benefits of resource diversification (Froelich, 1999; Carroll and Stater, 2009). Additionally a more explicitly normative literature highlights the supposed efficiency benefits of commercialisation (see for example Dees et al., 2001). However little is known as to whether nonprofits are increasingly diversifying away from grants and donations. Kerlin and Pollak (2011) do show that there was a gradual trend for the nonprofit sector to become more reliant on commercial revenue from 1982-2000.

Moreover much of the existing literature suggests that successful nonprofits are not adopting mixed revenue streams. Foster and Bradach (2005) found that the overall proportion of nonprofit funding sources has remained the same between 1977 and 1997. Foster, Dixon, and Hochstetler (2003) found that 27 of the 30 largest nonprofits identified in the Nonprofit Times' Top 100, relied on one source of funding for more than $50 \%$ of revenue. Therefore, it might be that portfolio theory is not a sufficiently powerful lens with which to fully understand nonprofits' revenue mixes.

\subsection{How stable are mixed revenue strategies over time?}

A developing stream of literature on nonprofits and hybridity suggests that the boundaries between nonprofits and other organisational types (private firms and public sector agencies) are becoming increasingly blurred (Billis, 2010; Mullins et al., 2012). In the traditional view of the three sector economy, organisations can be distinguished by the (financial) resources on which they rely. So the state funds its activities through taxation, private firms sell goods and services in the marketplace, and (pure) nonprofits attract private donations (Billis, 2010). There is wider dispute in the hybridity literature as to whether there is indeed a pure form of nonprofit, or whether instead nonprofits are (and always have been) hybrid organisations (see for example Evers and Svetlik, 1993). Nonetheless a general theme within the hybridity literature is that nonprofits find it difficult to balance the competing logics 
associated with commercial and donative types of funding, and that a balanced revenue mix may be unsustainable over time (Billis, 2010; Teasdale, 2012).

\subsection{Which organisations are adopting mixed revenue strategies?}

However one lesson from the hybridity literature is that it is important not to treat nonprofits as a homogenous entity. To some extent it would appear that revenue mix is influenced by field of activity. That is certain fields are more amenable to commercial revenue strategies. Bowman (2011) found that health, arts, and housing organisations derive $90 \%, 89 \%$, and $88 \%$ of their income, respectively, from earned income. In contrast, nonprofits working in the fields of animal, youth, and advocacy draw more than $90 \%$ of their revenue from private gifts and grants (Bowman, 2011). Foster and Bradach (2005) also found that between 1991 and 2001, earned income was concentrated in health and education organisations. After calculating a concentration index with a score of 1.0 representing complete concentration, Chang and Tuckman (1994) found that the mean concentration index of over 113,000 nonprofits in 26 activity categories ranged from 0.5 to 0.81 , indicating that nonprofits tend towards more concentrated revenue. Activity categories with higher concentration indices include health, consumer protection and legal aid, and housing, while arts, environment, and animal-related activity categories had the lowest mean concentration indices of approximately 0.5 .

Perhaps the best explanation for nonprofits' different revenue mixes is provided by Fischer, Wilkser and Young (2011). In fields such as human services where (more) nonprofits benefit the public good, a nonprofit is more likely to rely on donative revenue. Conversely in fields such as health where nonprofits compete with private organisations and where nonprofits produce private benefits, a nonprofit is more likely to rely on commercial revenue. In more mixed fields such as the arts, nonprofits would be expected to develop a more balanced revenue portfolio (Fischer, Wilsker and Young, 2011).

\section{Data and methods}

Our brief review of the literature highlighted three important research questions:

RQ1: To what extent (if at all) are nonprofits increasingly adopting mixed revenue strategies?

RQ2: How stable are mixed revenue strategies over time?

RQ3: Which organisations are adopting mixed revenue strategies?

To address these questions we constructed a panel derived from NCCS data that is drawn from IRS Forms 990 that 501 (c) (3) charitable organisations filed with the Internal Revenue Service (IRS). We believe that this data set contains the full population of non-religious 501(c) (3) organisations with annual revenue above $\$ 25,000$ filing IRS Form 990 in these years. The financial and other data from these files is collected in digitised form and constitute the Core datasets of the NCCS at The Urban Institute in Washington D.C. For this paper we drew upon data from nonprofits submitting IRS Forms 990 for the tax years ending 1998 and 2007. Our main variables of interest are commercial revenue (CR); donative revenue (DR); and total revenue (TR). The sum of commercial revenue and donative 
revenue is not always equal to total revenue as investment income and other miscellaneous sources are also important revenue sources for a relatively small number of nonprofits.

Our donative revenue (DR) variable directly equates to the NCCS variable public support (contributions and government grants), which itself was constructed by aggregating the sum of direct public support; indirect public support and government contributions and grants.

Following the convention used by Kerlin and Pollak (2011) we constructed our commercial revenue (CR) variable by summing the total of program service revenue; dues and assessments; revenue from special events; and income from sales and inventory.

Our total revenue (TR) variable directly equates to the NCCS variable Total Revenue. All financial variables have been adjusted for inflation using the US Consumer Price Index and priced in 2007 US dollars.

In both years for which our panel was constructed there was no IRS 990 form submitted by roughly a third of nonprofits listed in the CORE dataset. The Urban Institute estimates missing values/cases using the variable from a previous year's IRS submission. In the results presented in the next section we omit those observations and nonprofits for which data was estimated.

Our panel consisted of 188,658 nonprofits in 1998 and 271,668 nonprofits in 2007. Eight per cent of all cases had commercial revenue summing to more than $100 \%$ of total revenue. For this analysis these cases are treated as having $99-100 \%$ commercial revenue. 1,163 cases were treated as missing in 2007 as total revenue summed to less than zero. 762 cases were treated as missing as commercial revenue summed to less than zero.

The statistical methods we use for analysis are largely descriptive. Whereas previous studies have used parametric approaches to exploring non-profit revenue mixes, the wide diversity of nonprofits may make non-parametric techniques more appropriate for an exploratory study of this type.

\section{Empirical evidence}

This section is divided into four parts. First we show the characteristics of nonprofit revenue sources in 1998. This lends support to Hansmann's theory (1987) that most nonprofits cluster into two groups: donative and commercial. Second we show that (contravening much of the literature on hybridity and social enterprise) these characteristics remained remarkably similar in 2007. In the third section we draw upon a new 'matched sample' containing all those nonprofits for which we have observations in both 1998 and 2007. Here we explore the relative stability of our different groups of nonprofits - that is do they maintain their revenue mixes over time; and we also compare growth in total revenue by nonprofit group. Finally we pay particular attention to the characteristics of the small number of nonprofits which were mixed revenue in 1998 and 2007. What if, anything, were the particular characteristics of this group which enabled them to find stability of revenue mix?

\subsection{Characteristics of nonprofit revenue mixes in 1998}

We grouped our cases into three main groups based on the proportion of total revenue (TR) derived from commercial (\%CR) or donative revenues (\%DR) in $1998.29 \%$ of all nonprofits derived $90 \%$ or 
more of total revenue from commercial sources in 1998. In line with Hansmann (1987) we term these 'commercial nonprofits' (See Table 1). $23 \%$ of all nonprofits derived $90 \%$ or more of total revenue from grants and donations in 1998. We term these 'donative nonprofits'. Just $7.7 \%$ of nonprofits derived between 40 and $60 \%$ of total revenue from commercial sources in 1998 . We term this group 'mixed revenue nonprofits'.

Table 1. Characteristics of nonprofit revenue sources in 1998

\begin{tabular}{|c|c|c|c|c|c|c|}
\hline Category of nonprofit & & TR $(\$)$ & $\mathrm{DR}(\$)$ & $\mathrm{CR}(\$)$ & $\%$ DR & $\% \mathrm{CR}$ \\
\hline \multirow{4}{*}{ Donative nonprofits } & Mean & $1,647,912$ & $1,600,577$ & 30,196 & 97 & 02 \\
\hline & Median & 222,682 & 217,963 & 1.00 & 99 & 00 \\
\hline & $\mathrm{N}$ & 43,393 & 43,393 & 43,393 & 43,393 & 43,393 \\
\hline & $\%$ of sample & 23 & 23 & 23 & 23 & 23 \\
\hline \multirow{4}{*}{ Commercial nonprofits } & Mean & $8,023,093$ & 75,274 & $7,771,634$ & 06 & 98 \\
\hline & Median & 192,234 & 649 & 218,341 & 02 & 99 \\
\hline & $\mathrm{N}$ & 54,752 & 54,742 & 54,752 & 54,742 & 54,752 \\
\hline & $\%$ of sample & 29 & 29 & 29 & 29 & 29 \\
\hline \multirow{4}{*}{ Mixed Revenue nonprofits } & Mean & $5,367,253$ & $1,223,192$ & $2,778,747$ & 45 & 50 \\
\hline & Median & 263,558 & 113,478 & 131,744 & 47 & 50 \\
\hline & $\mathrm{N}$ & 14,493 & 14493 & 14,493 & 14,493 & 14,493 \\
\hline & $\%$ of sample & 7.7 & 7.7 & 7.7 & 7.7 & 7.7 \\
\hline \multirow{4}{*}{ All nonprofits } & Mean & $4,924,089$ & 920,660 & $3,371,283$ & 45 & 48 \\
\hline & Median & 241,549 & 64,900 & 64,141 & 38 & 46 \\
\hline & $\mathrm{N}$ & 187,969 & 188,640 & 188,033 & 187,951 & 187,387 \\
\hline & $\%$ of sample & 100 & 100 & 100 & 100 & 100 \\
\hline
\end{tabular}

Notes: variation in total revenues across groups is significant at $p<0.01$

As Table 1 would suggest there was considerable variation between the two main groups of nonprofits in 1998. Donative nonprofits tended to be smaller (with a mean TR of around $\$ 1.65$ million) than commercial nonprofits (with a mean TR of around $\$ 8$ million). Although for all nonprofits the mean percentages of $C R$ and DR were broadly similar, the mean $C R$ was around three and a half times larger than the mean DR. For the nonprofit sector CR is much more important than DR. However for the 'average nonprofit' the two revenue sources are almost equally important. The differences at the 
aggregate level are attributable to a relatively small number of very large nonprofits relying predominately on commercial revenue.

The distribution of commercial and donative revenue within nonprofits was dramatically polarised in 1998. Over half of all nonprofits in 1998 were either donative or commercial. That is they derived more than $90 \%$ of their income from one main revenue source. Figure 1 shows the distribution of commercial revenue within nonprofits in 1998.

\section{Figure 1. Distribution of commercial revenue within all nonprofits (1998)}

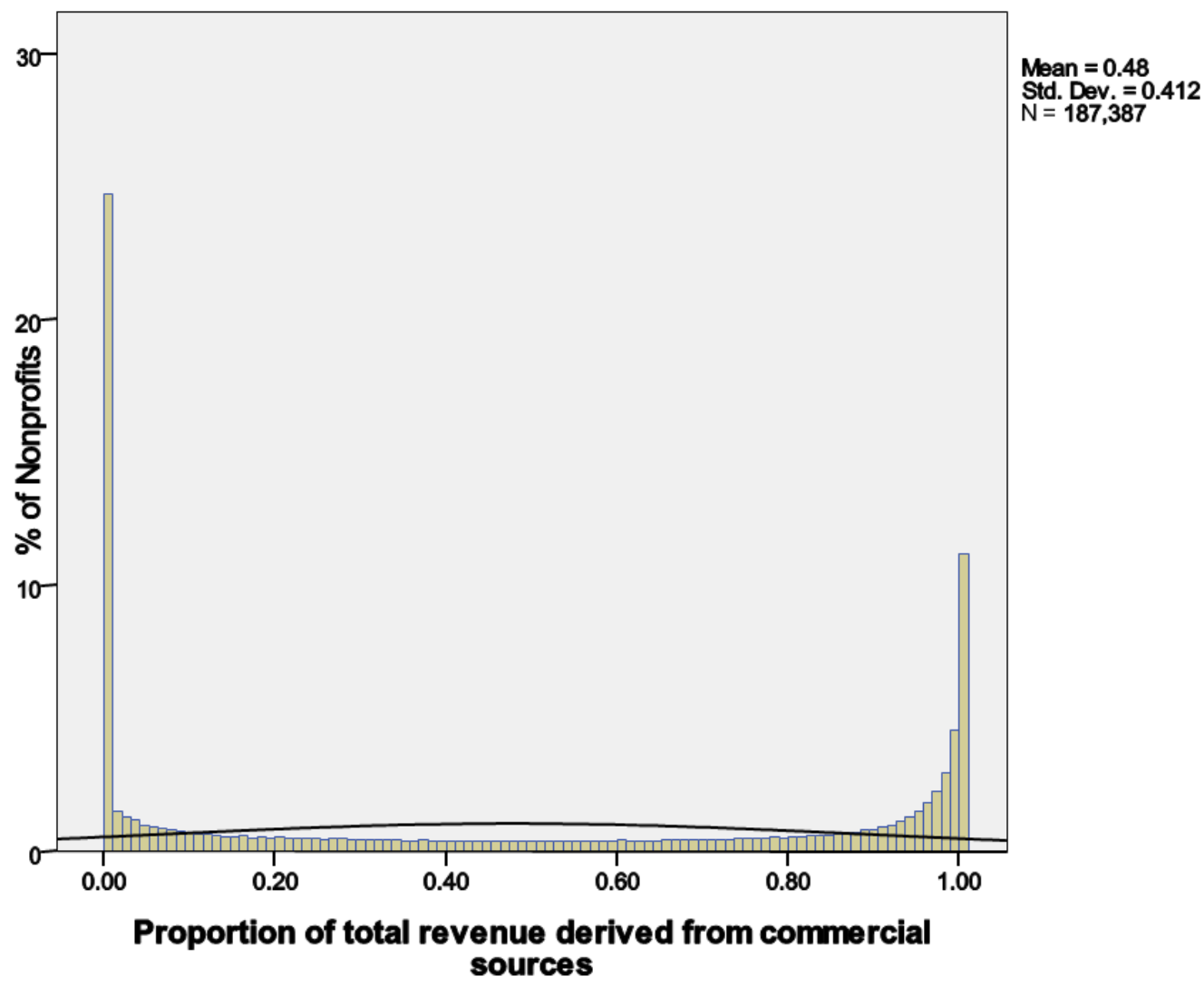

It would certainly appear that nonprofits cluster towards one or other of the extreme revenue mixes. This would lend support to Hansmann's (1987) sense that most nonprofits are either commercial or donative. Moreover we can say with some certainty that commercial nonprofits are larger than donative nonprofits. Of the 188,658 nonprofits in our sample for the tax year ending 1998, just 14,493 (7.7\%) derived a balanced mix of commercial and donative revenue (defined as $40-60 \%$ commercial revenue). Given the attention paid in recent academic literature to 1) the marketization of the nonprofit sector (Eikenberry and Kluver, 2005), 2) the development of mixed revenue sources to counteract resource dependence (Froelich, 1999) 3) hybrid nonprofits deriving income from multiple sources (Billis, 2010) and 4) the legitimacy of earned income approaches (Dart, 2004) one might have expected the proportion of commercial and mixed revenue nonprofits to have increased a decade later. In the next section we explore the extent to which this was the case. 


\subsection{Characteristics of nonprofit revenue mixes in 2007}

We expected both the proportion of mixed revenue nonprofits and the proportion of commercial nonprofits to have increased over the subsequent ten year period. However, although the number of mixed revenue nonprofits had increased to 20,560 , this represented just $7.6 \%$ of the 271,688 filing IRS 990 forms for the tax year ending 2007, a slightly lower proportion than in 1998 (See Table 2). The proportion of commercial nonprofits also fell slightly over the ten year period, from 29\% in 1998 to $28.1 \%$ in 2007 . This decrease was more than offset by a rise in the proportion of donative nonprofits, from $23 \%$ in 1998 to $27 \%$ in 2007.

Table 2. Characteristics of nonprofit revenue sources in 2007

\begin{tabular}{|c|c|c|c|c|c|c|}
\hline Category of nonprofit & & $\operatorname{TR}(\$)$ & $\mathrm{DR}(\$)$ & $\mathrm{CR}(\$)$ & $\% \mathrm{DR}$ & $\% \mathrm{CR}$ \\
\hline \multirow{4}{*}{ Donative nonprofits } & Mean & $1,729,531$ & $1,681,235$ & 34,346 & 98 & 04 \\
\hline & Median & 153,349 & 151,771 & 1.00 & 99 & 00 \\
\hline & $\mathrm{N}$ & 73463 & 73463 & 72805 & 73,463 & 72,805 \\
\hline & $\%$ of sample & 27 & 27 & 27 & 27 & 27 \\
\hline \multirow{4}{*}{ Commercial nonprofits } & Mean & $8,970,288$ & 105,204 & $8,645,520$ & 07 & 98 \\
\hline & Median & 128,362 & 1,030 & 146,603 & 01 & 100 \\
\hline & $\mathrm{N}$ & 76367 & 76,359 & 76,367 & 76,359 & 76,367 \\
\hline & $\%$ of sample & 28.1 & 28.1 & 28.1 & 28.1 & 28.1 \\
\hline \multirow{4}{*}{ Mixed Revenue nonprofits } & Mean & $3,887,918$ & $1,298,364$ & $1,936,822$ & 47 & 50 \\
\hline & Median & 192,821 & 87148 & 95,510 & 48 & 50 \\
\hline & $\mathrm{N}$ & 20,560 & 20,560 & 20,560 & 20,560 & 20,560 \\
\hline & $\%$ of sample & 7.6 & 7.6 & 7.6 & 7.6 & 7.6 \\
\hline \multirow{4}{*}{ All nonprofits } & Mean & $5,018,840$ & $1,096,897$ & $3,459,378$ & 48 & 46 \\
\hline & Median & 172,452 & 52,521 & 45,499 & 46 & 41 \\
\hline & $\mathrm{N}$ & 270,556 & 271,673 & 270,814 & 270,545 & 269,763 \\
\hline & $\%$ of sample & 100 & 100 & 100 & 100 & 100 \\
\hline
\end{tabular}

Notes: variation in total revenues across groups is significant at $p<0.01$

Figure 2 shows that the distribution of CR within nonprofits in 2007 was virtually identical to the distribution in 1998. There are no indications that nonprofits are increasingly drawing upon a more equal balance of resources. Nor are there any indications that nonprofits in 2007 derived a higher proportion of revenue from commercial sources. Any differences in patterns appear virtually indistinguishable to the naked eye. In 2007 (as in 1998) most derived their income predominately from 
one of the two major revenue sources. This would suggest that for most nonprofits, relying predominately on either commercial or donative revenue is a more stable equilibrium than attempting to achieve a balanced revenue mix. It would appear that Hansmann's (1987) typology of nonprofits still has relevance today.

Figure 2. Distribution of commercial revenue within all nonprofits (2007)

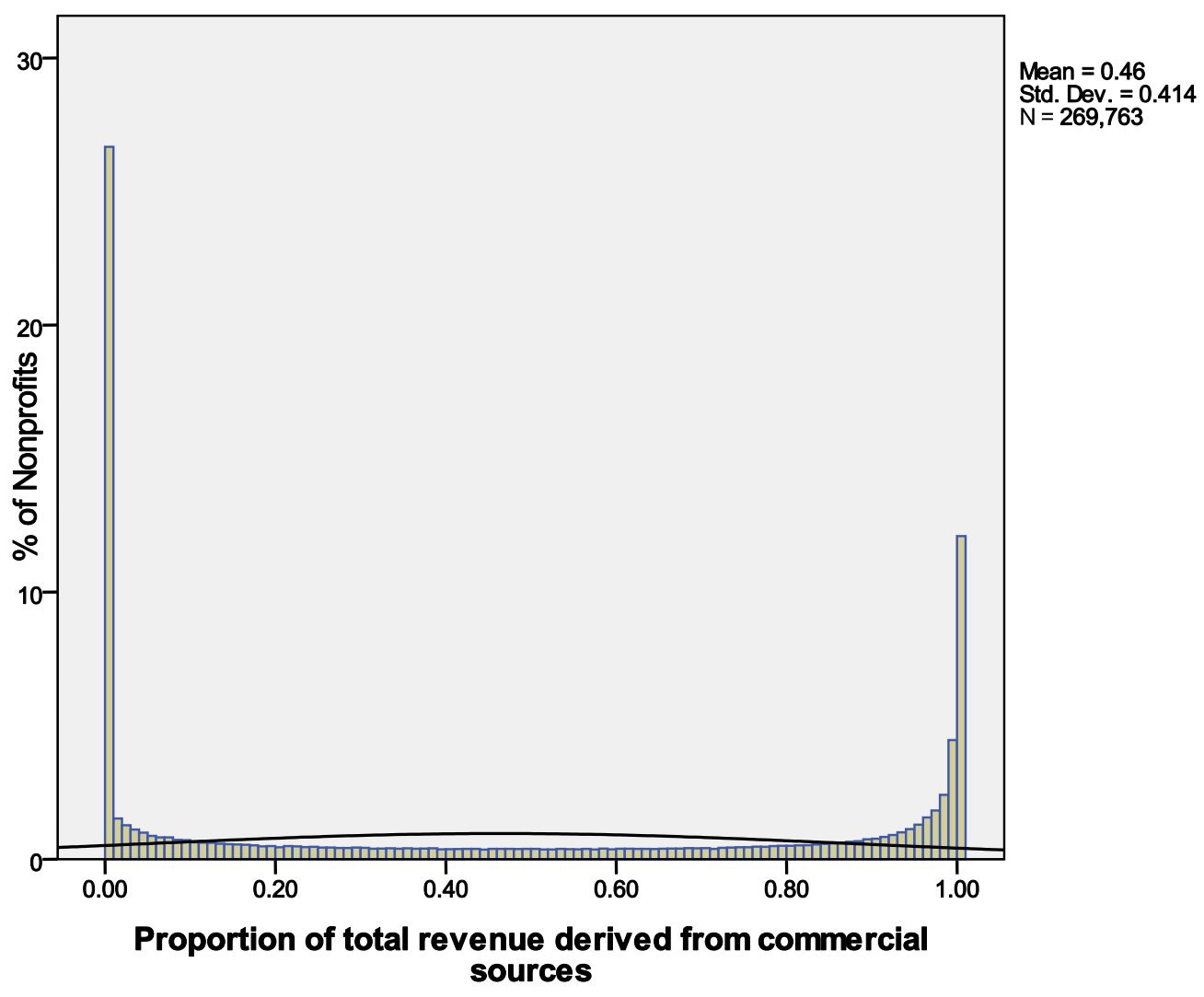

\subsection{The relative stability of different revenue mixes over time}

Up to this point we have explored the characteristics of nonprofit revenue sources at two different points of time. This has demonstrated that nonprofits in the US were no more likely (and indeed slightly less likely) to adopt mixed revenue strategies in 2007 than they were in 1998. Our second research question concerned the relative stability of different revenue mixes over time. To explore this we constructed a matched sample containing all 131,672 nonprofits for which we have observations in both 1998 and 2007. This represents around 70\% of all nonprofits for which we had data from 1998 . Table 3 shows the characteristics of the matched sample in 1998. 
Table 3. Characteristics of matched sample nonprofits revenue sources in 1998

\begin{tabular}{|c|c|c|c|c|c|c|}
\hline Category of nonprofit & & $\operatorname{TR}(\$)$ & $\mathrm{DR}(\$)$ & $\mathrm{CR}(\$)$ & $\% \mathrm{CR}$ & $\% \mathrm{DR}$ \\
\hline \multirow{4}{*}{ Donative nonprofits } & Mean & $2,072,391$ & $2,009,701$ & 38,648 & 2 & 97 \\
\hline & Median & 287,983 & 280,189 & 1 & 0 & 98 \\
\hline & $\Delta$ & \multicolumn{5}{|c|}{28,383} \\
\hline & $\%$ of sample & \multicolumn{5}{|c|}{21.6} \\
\hline \multirow{4}{*}{ Commercial nonprofits } & Mean & $9,814,184$ & 90,923 & $9,501,145$ & 98 & 6 \\
\hline & Median & 243,969 & 1,208 & 273,154 & 99 & 0 \\
\hline & $\mathrm{N}$ & \multicolumn{5}{|c|}{36,966} \\
\hline & $\%$ of sample & \multicolumn{5}{|c|}{28.1} \\
\hline \multirow{4}{*}{ Mixed Revenue nonprofits } & Mean & $4,857,644$ & $1,509,051$ & $2,464,164$ & 50 & 45 \\
\hline & Median & 320,543 & 137,611 & 159,165 & 50 & 47 \\
\hline & $\mathrm{N}$ & \multicolumn{5}{|c|}{10,666} \\
\hline & $\%$ of sample & \multicolumn{5}{|c|}{8.1} \\
\hline \multirow{4}{*}{ All nonprofits } & Mean & $5,710,319$ & $1,140,639$ & $3,958,093$ & 48 & 44 \\
\hline & Median & 305,775 & 79,691 & 77,389 & 46 & 38 \\
\hline & $\mathrm{N}$ & \multicolumn{5}{|c|}{131,672} \\
\hline & $\%$ of sample & \multicolumn{5}{|c|}{$100(69.8 \%$ of all nonprofits in 1998$)$} \\
\hline
\end{tabular}

As might be expected, the mean total revenue for all groups of nonprofits in our matched sample was higher than for comparative groups in the wider sample because our matched sample over represents larger nonprofits. Perhaps larger nonprofits were more likely to be in existence ten years later (and hence file an IRS 990 Form). To some extent then, by virtue of being in the matched sample, nonprofits themselves must be financially sustainable (although note this does not necessarily mean that their revenue mix is sustainable).

The distribution of nonprofits by revenue group was broadly similar to the wider sample among our matched sample. Interestingly mixed revenue nonprofits were slightly overrepresented in our matched sample $(8.1 \%$ of the sample compared to $7.7 \%$ of the wider sample), while both donative and commercial nonprofits were slightly underrepresented. It should be noted that not filing an IRS 990 form does not necessarily mean a nonprofit no longer exists. As discussed in the methods section, around a third of (mainly smaller) nonprofits in any given year do not file an IRS 990 form. 
Nonetheless this would appear to lend tentative support to portfolio theory as applied to nonprofits. That is nonprofits with a broadly equal split between commercial and donative revenue in 1998 were comparatively more likely to file IRS 990 Forms in 2007.

Table 4 shows the characteristics of our matched sample in 2007. It is particularly interesting to note the apparent stability of revenue mix among all groups of nonprofits. Nonprofits which were donative in 1998 derived on average $82 \%$ of their total revenue from grants and donations a decade later. Nonprofits which were commercial in 1998 derived on average $87 \%$ of their total revenue from commercial sources in 2007. Nonprofits which were mixed revenue in 1998 on average derived an almost identical proportion of total revenue from commercial and donative sources a decade later. This would seem to demonstrate a remarkable stability of commercial and donative revenue over time.

Table 4. Characteristics of matched sample nonprofits revenue sources in 2007

\begin{tabular}{|c|c|c|c|c|c|c|}
\hline Category of nonprofit & & $\mathrm{TR}(\$)$ & $\mathrm{DR}(\$)$ & $\mathrm{CR}(\$)$ & $\% \mathrm{CR}$ & $\% \mathrm{DR}$ \\
\hline \multirow{4}{*}{ Donative nonprofits } & Mean & $3,260,032$ & $2,733,738$ & 361,489 & 15 & 82 \\
\hline & $\mathrm{N}$ & \multicolumn{5}{|c|}{28,383} \\
\hline & $\%$ of sample & \multicolumn{5}{|c|}{21.6} \\
\hline & Median & 392,620 & 289,025 & 4,606 & 1 & 95 \\
\hline \multirow{4}{*}{ Commercial nonprofits } & Mean & $14,927,227$ & 370,457 & 14009,775 & 87 & 13 \\
\hline & $\mathrm{N}$ & \multicolumn{5}{|c|}{36,966} \\
\hline & $\%$ of sample & \multicolumn{5}{|c|}{28.1} \\
\hline & Median & 297,627 & 5,150 & 256,180 & 98 & 1 \\
\hline \multirow{4}{*}{ Mixed Revenue nonprofits } & Mean & $6,445,705$ & $1,982,864$ & 3428,055 & 51 & .44 \\
\hline & $\mathrm{N}$ & \multicolumn{5}{|c|}{10,666} \\
\hline & $\%$ of sample & \multicolumn{5}{|c|}{8.1} \\
\hline & Median & 441,090 & 160,318 & 178,264 & 50 & 44 \\
\hline \multirow{4}{*}{ All nonprofits } & Mean & $8,528,909$ & $1,710,185$ & 6009,523 & 49 & 43 \\
\hline & $\mathrm{N}$ & \multicolumn{5}{|c|}{131,672} \\
\hline & $\%$ of sample & \multicolumn{5}{|c|}{$100(48.5 \%$ of all nonprofits in 2007$)$} \\
\hline & Median & 389,362 & 91,974 & 99,041 & 48 & 35 \\
\hline
\end{tabular}

Figures 3 and 4 graphically represent the distribution of commercial revenue in 2007 among nonprofits which were donative/commercial in 1998 . The general picture is that mainly commercial and mainly donative revenue mixes remain remarkably similar over time. 
Figure 3. Distribution of commercial revenue in 2007 within 1998 matched sample donative nonprofits

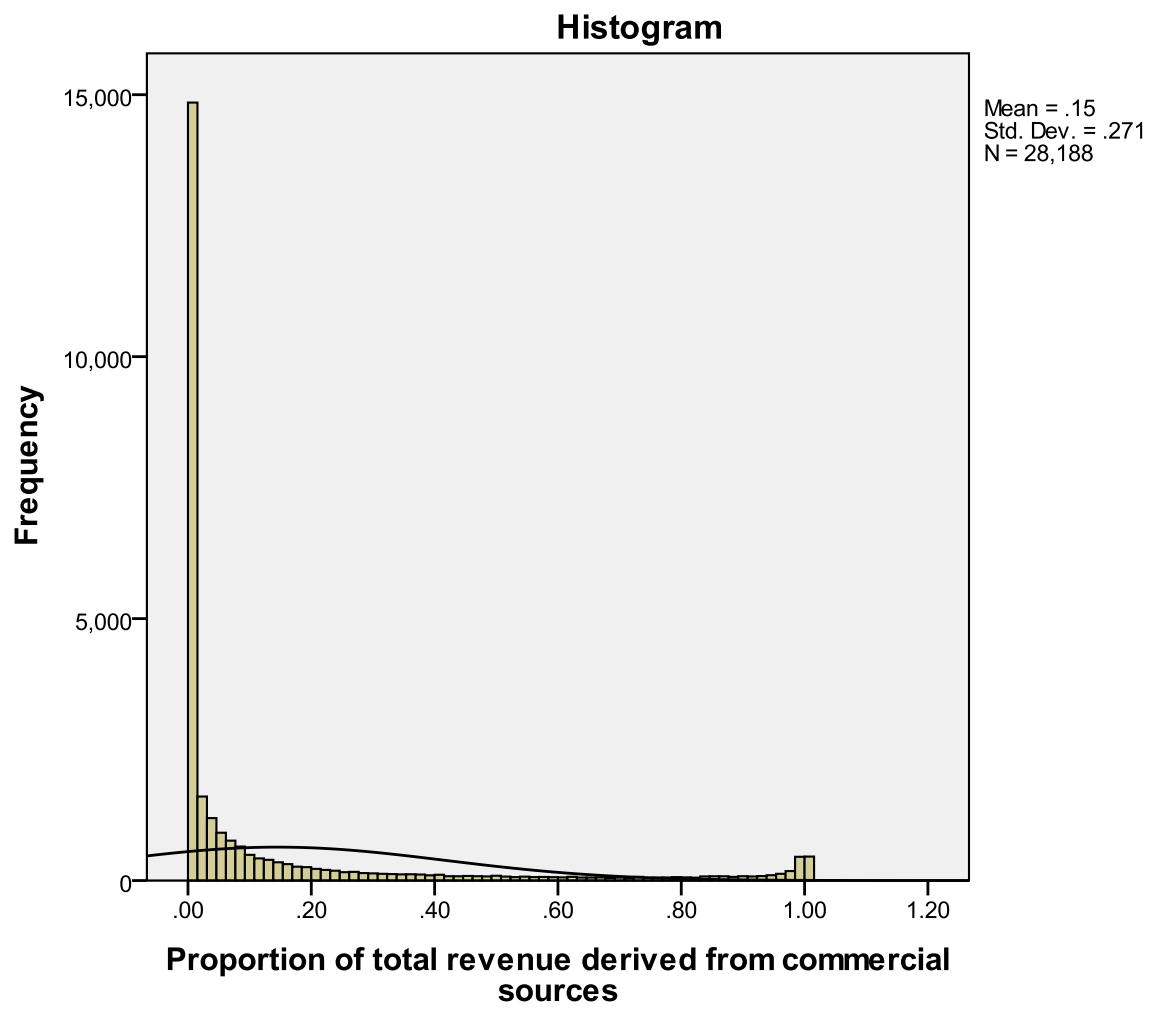

Figure 4. Distribution of commercial revenue in 2007 within 1998 matched sample commercial nonprofits

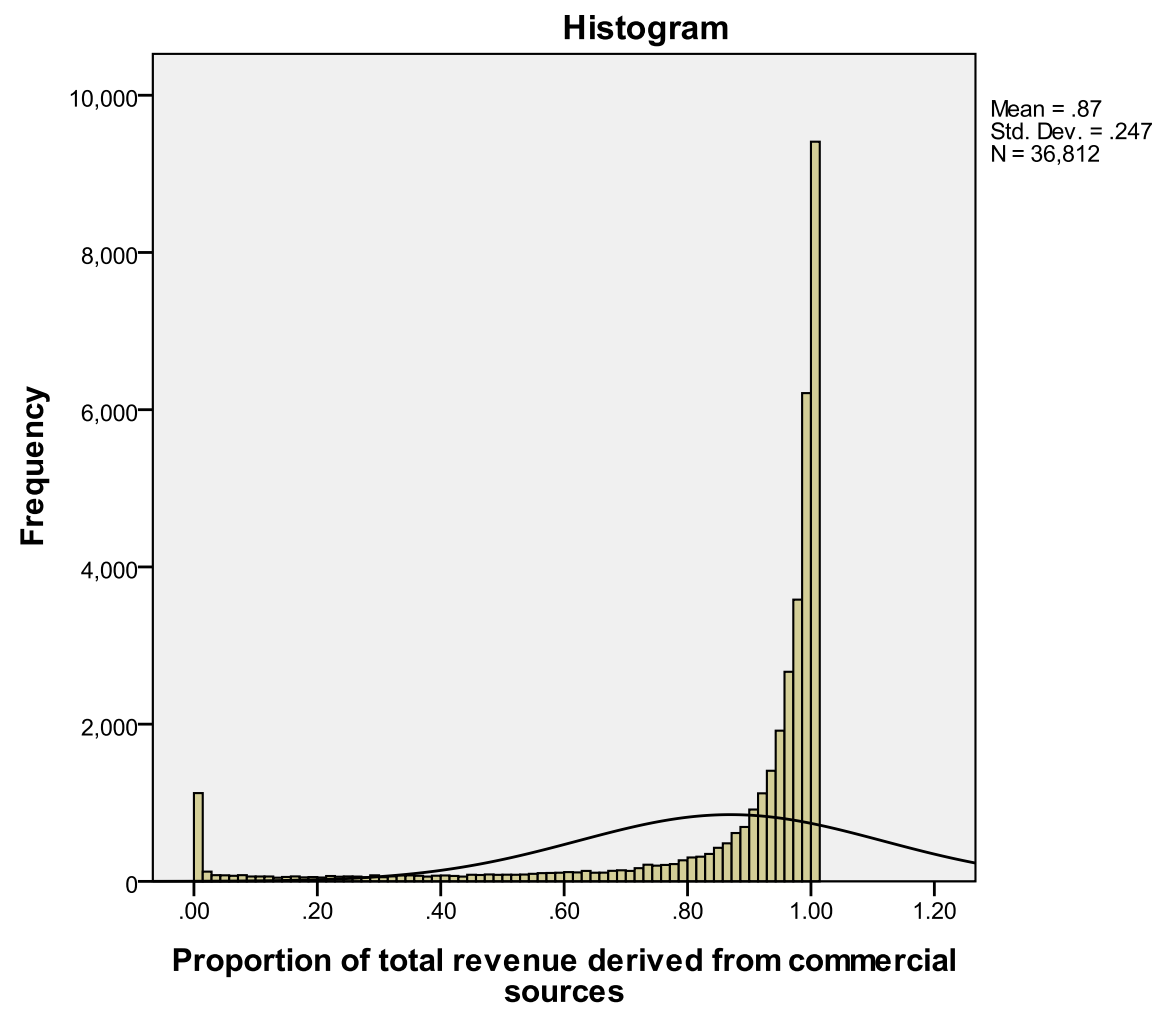


This is further supported when we explore the stability of donative and commercial revenues over time. In Tables 5 and 6 respectively we report the correlation matrices between commercial revenue in 1998 and 2007, and donative revenue in 1998 and 2007 respectively for all nonprofits in the matched sample. The correlations are remarkably high $(76.8 \%$ for commercial revenue and $74.6 \%$ for donative revenue) and significant $(p<0.01)$. Around three quarters of a nonprofit's revenue mix in 2007 could be predicted from their revenue mix in 1998.

Table 5. Matched sample: correlation between commercial revenue in 1998 and 2007

\begin{tabular}{|c|c|c|c|}
\hline & & $\begin{array}{l}\text { Proportion of total revenue } \\
\text { derived from commercial } \\
\text { sources in } 1998\end{array}$ & $\begin{array}{l}\text { Proportion of total revenue } \\
\text { derived from commercial } \\
\text { sources in } 2007\end{array}$ \\
\hline \multirow{3}{*}{$\begin{array}{l}\text { Proportion of total revenue } \\
\text { derived from commercial } \\
\text { sources in } 1998\end{array}$} & $\begin{array}{l}\text { Pearson } \\
\text { Correlation }\end{array}$ & 1 & $.768^{x \times}$ \\
\hline & Sig. (2-tailed) & & .000 \\
\hline & $\mathrm{N}$ & 130897 & 130218 \\
\hline \multirow{3}{*}{$\begin{array}{l}\text { Proportion of total revenue } \\
\text { derived from commercial } \\
\text { sources in } 2007\end{array}$} & $\begin{array}{l}\text { Pearson } \\
\text { Correlation }\end{array}$ & $.768^{* *}$ & 1 \\
\hline & Sig. (2-tailed) & .000 & \\
\hline & $\mathrm{N}$ & 130218 & 130847 \\
\hline
\end{tabular}

${ }^{* *}$. Correlation is significant at the 0.01 level (2-tailed).

Table 6: Matched sample: correlation between donative revenue in 1998 and 2007

\begin{tabular}{|c|c|c|c|}
\hline & & $\begin{array}{l}\text { Proportion of total revenue } \\
\text { derived from donative } \\
\text { revenue in } 1998\end{array}$ & $\begin{array}{l}\text { Proportion of total revenue } \\
\text { derived from donative } \\
\text { revenue in } 2007\end{array}$ \\
\hline \multirow{3}{*}{$\begin{array}{l}\text { Proportion of total revenue } \\
\text { derived from donative } \\
\text { revenue in } 1998\end{array}$} & $\begin{array}{l}\text { Pearson } \\
\text { Correlation }\end{array}$ & 1 & $.746^{* x}$ \\
\hline & Sig. (2-tailed) & & .000 \\
\hline & $\mathrm{N}$ & 131262 & 130868 \\
\hline \multirow{3}{*}{$\begin{array}{l}\text { Proportion of total revenue } \\
\text { derived from donative } \\
\text { revenue in } 2007 \text { donations }\end{array}$} & $\begin{array}{l}\text { Pearson } \\
\text { Correlation }\end{array}$ & $.746^{* x}$ & 1 \\
\hline & Sig. (2-tailed) & .000 & \\
\hline & $\mathrm{N}$ & 130868 & 131202 \\
\hline
\end{tabular}


When we turned our attention to those nonprofits which adopted a balanced revenue portfolio in 1998, we found that most of these were passing through a temporary stage rather than a settled equilibrium, perhaps as part of a process of restructuring their funding activities. Figure 5 shows the distribution of commercial revenue in 2007 only for the 10,622 nonprofits which were mixed revenue in 1998 . The distribution of commercial revenue around the mean (and /or median) is almost 'normal', albeit with relatively large proportions with all or no commercial revenue. This is however more than would have occurred if the mixed revenue group were redistributed randomly in 2007, in which case we would have expected to see a distribution more closely approximating that in Figure 2. It would therefore appear that mixed revenue nonprofits in 1998 were more likely than the wider sample to be mixed revenue in 2007.

Figure 5. Distribution of commercial revenue in 2007 within 1998 matched sample mixed revenue nonprofits

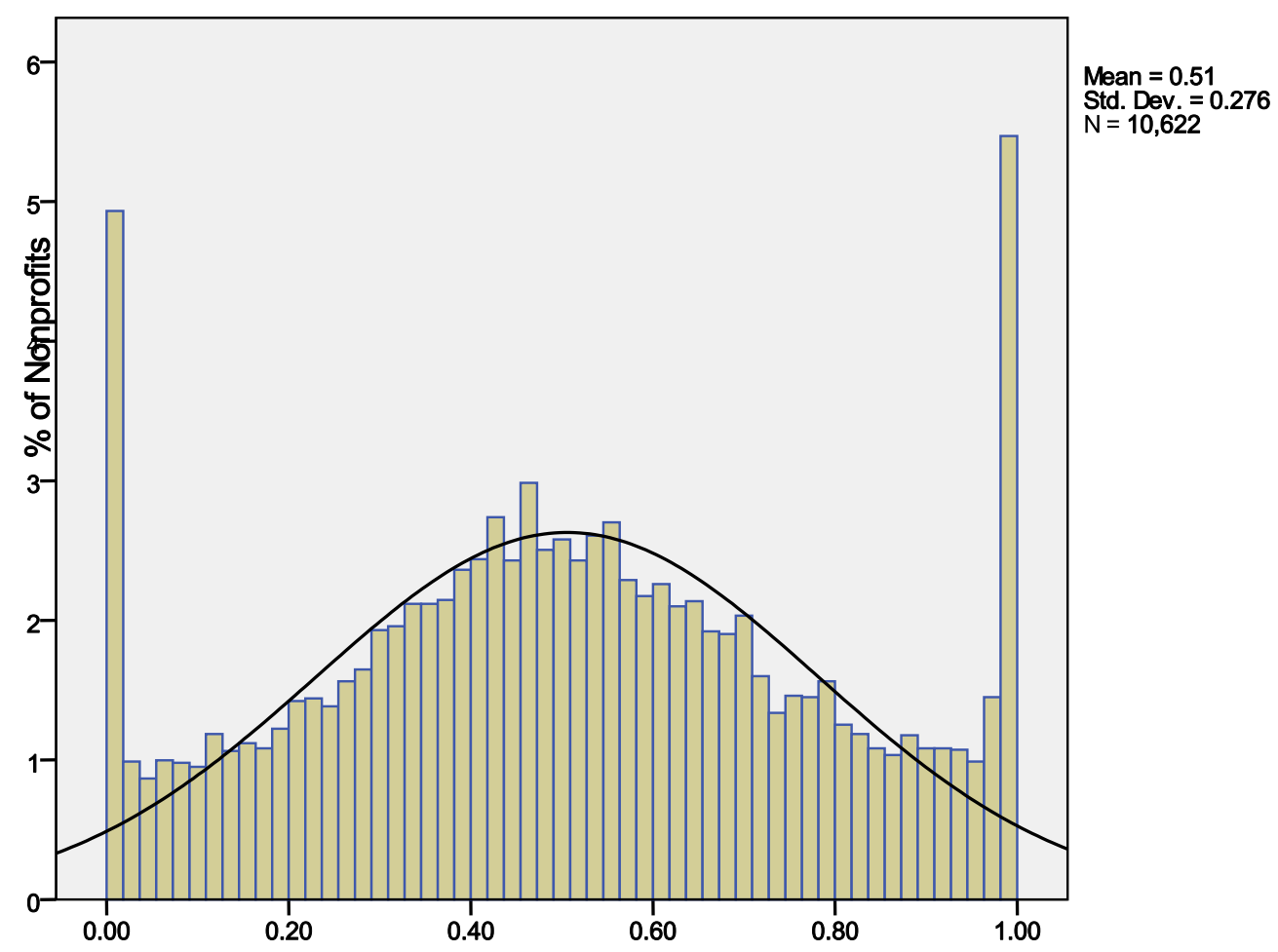

Proportion of total revenue derived from commercial sources

\subsection{Characteristics of stable mixed revenue nonprofits}

Even so, just 2,961 nonprofits were mixed revenue in 1998 and also in 2007 . This equated to $1.6 \%$ of our original 1998 sample. So what, if anything, distinguishes those mixed revenue nonprofits which maintained a diverse revenue mix between 1998 and 2007? As a group they have experienced 35\% growth over the 10 year period, from mean total revenue of just under $\$ 8.5$ million in 1998 to $\$ 11.5$ million in 2007. Around $\$ 1.5$ million of this growth came from commercial revenue and $\$ 800,000$ from 
grants and donations. However this growth is significantly smaller in percentage terms than the $49 \%$ increase in total revenue for all nonprofits in the matched sample (See Table 7).

Table 7. Inflation adjusted growth in total revenue between 1998 and 2007 for different groups on nonprofit in our matched sample.

\begin{tabular}{lrrrr}
\hline & All cases & $\begin{array}{r}1998 \text { Donative } \\
\text { nonprofits }\end{array}$ & $\begin{array}{r}1998 \text { Hybrid } \\
\text { nonprofits }\end{array}$ & $\begin{array}{r}1998 \text { Commercial } \\
\text { nonprofits }\end{array}$ \\
\hline Mean TR $(\$) 1998$ & $5,710,319$ & $2,072,391$ & $4,857,641$ & $9,814,184$ \\
$\mathrm{n}$ & 131,275 & 28,383 & 10,666 & 36,966 \\
Mean TR $(\$)$ 2007 & $8,528,908$ & $3,260,032$ & $6,445,705$ & $14,927,227$ \\
$\mathrm{n}$ & 131,206 & 28,319 & 10,648 & 36,833 \\
$\begin{array}{l}\text { \$ Change in Mean TR } \\
\text { since 1998 }\end{array}$ & $2,818,589$ & $1,187,641$ & $1,588,064$ & $5,113,043$ \\
$\begin{array}{l}\text { \% Change in Mean TR } \\
\text { since 1998 }\end{array}$ & $49.4 \%$ & $57.3 \%$ & & $52.7 \%$ \\
\hline
\end{tabular}

Variation is significant at 0.01 using one-way Anova

Table 7 shows that nonprofits which were mixed revenue in 1998 grew their total revenue at a slower rate $(32.7 \%)$ than either commercial $(52.1 \%)$ or donative nonprofits $(57.3 \%)$. To some extent this offers further support to portfolio theory as applied to nonprofits. That is nonprofits would seem to be able to accept a higher chance of survival in exchange for a lower growth rate by adopting balanced revenue strategies. However this analysis is incomplete. It should be noted that both commercial and donative nonprofits grew faster than the average for all nonprofits. Adherents of portfolio theory might have expected mixed revenue profits to fall between fastest growing (donative) nonprofits and slower growing (commercial) nonprofits. Therefore it would appear that something else is going on which might better explain mixed revenue profits lower growth.

When compared to the wider sample for which we have observations in both years, consistently mixed revenue nonprofits are overrepresented in the smallest size groups (less than \$1 million) and underrepresented in the largest size groups (more than $\$ 1$ million).

Twenty seven per cent of consistently mixed revenue nonprofits were in the NTEE (National Taxonomy of Exempt Entities) subgroup Arts, Culture, and Humanities, as compared to $10.5 \%$ of the wider sample for which we have observations in both years. Consistent mixed revenue nonprofits were significantly overrepresented to a lesser extent in Youth Development (4.7\% compared to $2.7 \%$ ). Both of these NTEE groups contained a relatively low proportion (less than half) of nonprofits deriving either less than $10 \%$ or more than $90 \%$ of revenue from commercial sources. Moreover, consistent mixed revenue nonprofits were underrepresented particularly in NTEE subgroups Education $11.4 \%$ compared to $16.4 \%$ ); and Religion Related (3.2\% compared to $5.1 \%$ ). Each of these NTEE groups contained a relatively high proportion (over $70 \%$ ) of nonprofits deriving either less than $10 \%$ or more 
than $90 \%$ of revenue from commercial sources. Thus the groups within which mixed revenue nonprofits were clustered were those that contained relatively low proportions of nonprofits deriving (almost) all or none of their revenue from commercial sources.

\section{Discussion and conclusion}

Considerable attention has been paid in the research literature to the phenomena of hybridity. One element of this posits that by diversifying revenue streams, nonprofits can achieve an optimal balance between financial risk and reward. In this exploratory paper we have drawn upon NCCS CORE data from 1998 and 2007 to show that (between these two time points at least) nonprofits have become slightly less likely to adopt a revenue portfolio with relatively balanced proportions of commercial and donative revenue. Moreover, the majority of nonprofits adopting a balanced revenue portfolio in 1998 appear to have been passing through a temporary stage of balanced revenue en route to a more stable mix. Mixed revenue strategies were less sustainable ${ }^{2}$ over the time period than primarily donative or primarily commercial strategies. It is important to note this does not imply the mixed revenue nonprofit per se. is unsustainable.

Our data and the wider literature allow us to make tentative propositions as to why this may be the case. First, modern portfolio theory may not be wholly adequate for understanding nonprofits' revenue mixes. Certainly nonprofits with a balanced revenue portfolio in 1998 were comparatively more likely to file an IRS 990 form in 2007 than either donative or commercial nonprofits. While this is not a particularly reliable indicator of financial stability, it does offer some support to portfolio theory and the notion that adopting diversified revenue streams with relatively low covariance reduces risk. Additionally nonprofits with a balanced revenue portfolio in both 1998 and 2007 grew at a slower rate than the wider population. This would seem to confirm the trade-off between risk and reward implied by portfolio theory. However, it should be noted that mixed revenue nonprofits grew at a slower rate than either commercial or donative nonprofits. This is not consistent with portfolio theory which would predict that (ceteris paribus) mixed revenue nonprofits would grow at a rate in between commercial and donative nonprofits.

The academic literature helps explain this. Whereas for investors there are relatively few costs in diversifying into new stocks, for nonprofits the costs of diversifying from donative to commercial revenue may be substantial. Frumkin and Keating (2011) show that nonprofits with concentrated revenue portfolios experience considerably lower administrative costs. On a related note, much of the existing literature drawing upon portfolio theory assumes there is no substitution effect between commercial and donative revenue (see for example Carroll and Stater, 2009). Of course this is largely appropriate with regard to stock picking by investors. But for nonprofits it may be that the costs associated with revenue diversification partially (or indeed fully) offset any reduced volatility. Indeed, when using the latest econometric techniques, studies have shown a fairly substantial substitution effect between commercial and donative revenue (McKay et al., 2011). Therefore (on average) both donative and commercial nonprofits might be expected to show higher revenue growth than mixed revenue nonprofits. 
So it would appear that nonprofits are not increasingly adopting balanced revenue portfolios. However this is an aggregate picture and there may be subpopulations where this is happening. Indeed, for a small minority of nonprofits (1.6\% of all nonprofits in 1997), a balanced revenue mix would appear to represent a more stable equilibrium. These consistent mixed revenue nonprofits showed lower growth across all revenue sources than the wider population. They were particularly overrepresented in Arts, Culture, and Humanities, which was home to $27 \%$ of them (as compared to $10.5 \%$ of the wider population). They were also overrepresented in the smallest size groups (less than $\$ 1$ million). Earlier work by Fischer et al. (2011) may help to understand this. According to Fischer et al. (2011), the financing of nonprofits is heavily dependent on the types of services they provide. Nonprofits producing goods and services primarily benefitting specific recipients would be expected to rely more in program service revenues, whereas nonprofits providing goods and services benefitting the greater society would be expected to rely more upon grants and donations. Thus nonprofits offering mixed public and private goods and services would be more likely to have a mix of donative and commercial revenues. It seems, therefore, that mixed revenue strategies may be natural or intrinsic to a few NTEE and size groups of nonprofits that have special appeal to both paying customers and philanthropic donors, most notably in the arts, for example, where opera or orchestra goers are also donors.

\subsection{Implications for the future understanding of nonprofits' revenue mixes}

Our findings are necessarily tentative given the exploratory nature of our research. As such they have certain limitations. Firstly, our study is limited through relying only on two points in time. In this paper we are presenting early findings from a larger study of longitudinal revenue mixes, and chose to use two time points to enable graphical representation of change over time. We are confident that the distribution of commercial revenue within nonprofits was consistent in each year of the decade for which we have data. However it is likely that the changes in revenue vary considerably dependent upon which time points are chosen, and so these in particular should be treated with caution. The relative growth rates of different groups of nonprofits were not a major part of this study. Nonetheless the findings opened up important questions for future research concerning the trade-off between risk and reward. To better understand the relative growth rates between different groups of nonprofits, more controls for field, size and organisational age are necessary.

Second, the categories 'donative' and 'commercial' revenue are necessarily broad when using the NCCS CORE dataset. It may be that where nonprofits do diversify it is within different types of donative or commercial revenue - i.e. appealing to new donors, or developing additional products for sale. Further exploration using the SOI (Statistics of Income Sample) dataset could start to unpack this in more detail. Unfortunately research using the SOI and CORE datasets is constrained by the purposes for which this data was collected. A fuller understanding of nonprofits' revenue mixes may require the collection of new data. This is time consuming and using smaller datasets makes it difficult to include controls for field, size and organisational age.

Our analysis was mainly descriptive. This was partly to counterbalance a strong reliance on parametric models and limited concern for data exploration (including testing for the presence of 
outliers) in the existing literature. We believe that non parametric approaches may be the best way to develop a dynamic understanding of nonprofit revenue mixes in the future.

In the future we propose to divide nonprofits into three groups (primarily donative, primarily commercial, and mixed revenue) based on their revenue mix. Revenue mix will be calculated by expressing donative revenue as a proportion of commercial revenue. ${ }^{3}$ We will then repeat this for each year for which we have data over a thirteen year period in the US, (1998-2010). The unit of analysis then becomes the longitudinal revenue mix. This creates $3^{13}$ possibilities of revenue mix- many of which we expect will be empty. We will then explore which revenue typologies are experienced by which nonprofits (by size, field, and date of formation). The creation of such a set of sequences enables the use of 'optimal matching analysis' as part of the drive to identify patterns (see Chan, 1995).

Having derived this typology and tracked its path over time, we can relate this to changes in revenue growth and in the mix of revenue over time. Do organisations begin with dependence on particular income streams and then diversify? How do any such effects vary by size of organisation and by sector? Which revenue typologies are most successful (in terms of growth in total revenue; surplus)? This is likely to have an impact beyond academia as it will seek to identify those funding strategies and organisational characteristics that are more successful over time.

\footnotetext{
${ }^{1}$ Nonprofits' income can also be divided by source i.e. government, private individuals or private firms. The source and type do not neatly map onto each other. For example government may fund nonprofits through grants (donative revenue) or contracts (commercial revenue). In this paper we focus on type of income mainly because the dataset we draw upon does not distinguish between sources of income. ${ }^{2}$ We are not saying that the nonprofits themselves are unsustainable, rather that most of them do not sustain a mixed revenue portfolio over time.

${ }^{3}$ The small number of organisations with significant revenue from investment income will be analysed separately as we expect this to have a significant impact on their revenue volatility.
} 
Arellano, M. (2003) Panel data econometrics. Oxford: Oxford University Press.

Billis, D. (2010) 'Towards a theory of hybrid organisations' in D. Billis (ed.) Hybrid Organisations and the Third Sector. London: Palgrave.

Bond, S. (2002) Dynamic panel data models: a guide to microdata methods and practice. London: Cemmap Working Papers, CWP09/02.

Bowman, W. (ed.) (2011) Beyond Sustainability: Managing Revenue to Maximise Growth. Hoboken, $\mathrm{NJ}$ : Wiley.

Carroll, D. A. and Stater, K. J. (2009) 'Revenue Diversification in Nonprofit Organisations: Does it Lead to Financial Stability?' Journal of Public Administration Research and Theory, 19 (4), 947-66.

Chan, T. W. (1995) 'Optimal Matching Analysis: A Methodological Note on Studying Career Mobility', Work and Occupations, 22 (4), 467-90.

Chang, C. and Tuckman, H. (1994) 'Revenue diversification among non-profits'. Voluntas, 5 (3), 27390.

Dart, R. (2004) 'The legitimacy of social enterprise'. Nonprofit Management and Leadership, 14 (4), 411-24.

Dees, J. G., Emerson, J. and Economy, P. (2001) Enterprising Nonprofits: A toolkit for social entrepreneurs. New York: John Wiley and Sons.

Eikenberry, A. and Kluver, J. (2004)' The marketisation of the nonprofit sector: Civil society at risk?' Public Administration Review, 64 (2), 132-40.

Evers, A. and Svetlik, I. (eds) (1993) Balancing Pluralism. Vienna: Avebury.

Fischer, R. L., Wilsker, A. L. and Young, D. R. (2011) 'Exploring the Revenue Mix of Nonprofit Organisations - Does it relate to Publicness?' Nonprofit and Voluntary Sector Quarterly, 40 (4), 662-81.

Foster, W. and Bradach, J. (2005) 'Should Nonprofits Seek Profits?' Harvard Business Review, 83, 92-100.

Foster, W. and Fine, G. (2007) 'How Nonprofits Get Really Big'. Stanford Social Innovation Review, Spring, 46-55.

Foster, W., Dixon, B. and Hockstetler, M. (2003) Funding: Patterns and Guideposts in the Nonprofit Sector. The Bridgespan Group, www.bridgespan.org/getattachment/bbdad5b9-8f5f-41c2-821ca474c58cfb58/Funding-Patterns-and-Guideposts-in-the-Nonprof.aspx.

Froelich, K. (1999) 'Diversification of Revenue Strategies: Evolving Resource Dependence in Nonprofit Organisations'. Nonprofit and Voluntary Sector Quarterly, 28 (3), 246-68.

Frumkin, P. and Keating, E. K. (2011) 'Diversification Reconsidered: The Risks and Rewards of Revenue Concentration'. Journal of Social Entrepreneurship, 2 (2), 151-64.

Hansman, H. (1987) 'Economic theories of nonprofit organisation' in W. Powell (ed.) The nonprofit sector: A research handbook. New Haven: Yale University Press. 
Kerlin, J. A. and Pollak, T. (2011) 'Nonprofit Commercial Revenue: A Replacement for Declining Government Grants and Private Contributions?' American Review of Public Administration, 41 (6), 686-705.

Kim, P. and Bradach, J. (2012) 'Why More Nonprofits Are Getting Bigger'. Stanford Social Innovation Review, Spring, 14-16.

Markowitz, H. (1952) 'Portfolio selection'. The Journal of Finance, 7 (1), 77-91.

McKay, S., Moro, D., Teasdale, S. and Clifford, D. (2011) The marketisation of charities in England and Wales. Birmingham: Third Sector Research Centre Working Paper No. 69.

Mullins, D., Czischke, D. and van Bortel, G. (2012) 'Exploring the meaning of hybridity and social enterprise in housing organisations'. Housing Studies, 27 (4), 405-417.

Teasdale, S. (2012) 'Negotiating tensions: how do social enterprises in the homelessness field balance social and commercial considerations?' Housing Studies, 27 (4), 514-32.

Weisbrod, B. A. (1998) 'The nonprofit mission and its financing: growing links between nonprofits and the rest of the economy' in B. A. Weisbrod (ed) To profit or not to profit. Cambridge: Cambridge University Press, 1-24.

Yetman, M., Yetman, R. and Badertscher, B. (2009) 'Calibrating the reliability of publicly available nonprofit taxable activity disclosures: Comparing IRS 990 and IRS 990- T data'. Nonprofit and Voluntary Sector Quarterly, 38(1): 95-116.

Young, D. R. (ed.) (2007) Financing Nonprofits. Lanham, MD: AltaMira Press.

Young, D., Kerlin, J., Teasdale, S. and Soh, J. (2012) 'The dynamics and long-term stability of social enterprise' in. J. Kickul and S. Bacq (eds) Patterns in social entrepreneurship research. Cheltenham: Edward Elgar. 


\section{About the Centre}

The third sector provides support and services to millions of people. Whether providing front-line services, making policy or campaigning for change, good quality research is vital for organisations to achieve the best possible impact. The Third Sector Research Centre exists to develop the evidence base on, for and with the third sector in the UK. Working closely with practitioners, policy-makers and other academics, TSRC is undertaking and reviewing research, and making this research widely available. The Centre works in collaboration with the third sector, ensuring its research reflects the realities of those working within it, and helping to build the sector's capacity to use and conduct research.

Third Sector Research Centre, Park House, 40 Edgbaston Park Road,

University of Birmingham, Birmingham, B15 2RT

Tel: 01214143086

Email: info@tsrc.ac.uk

www.tsrc.ac.uk

\section{Economic and Social IImpact}

Assessing the economic impact of third sector organisations is a key research priority for TSRC. It is linked to our mapping and measuring of the sector, and has a particular focus on the role that third sector organisations play in delivering public services and contributing to general community wellbeing. We are engaged in a review of the wide range of existing methods and tools for measuring impact within TSOs including Social Return on Investment (SROI), blended impact measures and other adaptations of cost/benefit analysis. We will also develop sector wide analysis of economic impact of third sector activity and its contribution to the wider economy, including analysis of workforce trends, volunteering and third sector value.

\section{Contact the author}

\section{Simon Teasdale}

\section{s.teasdale@tsrc.ac.uk}

\section{8}

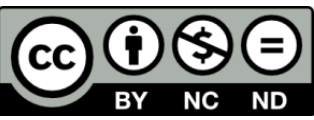

This work is licensed under the Creative Commons Attribution-NonCommercialNoDerivs 3.0 Unported License.

TSRC 2013

The support of the Economic and Social Research Council (ESRC), the Office for Civil Society (OCS) and the Barrow Cadbury UK Trust is gratefully acknowledged. The work was part of the programme of the joint ESRC, OCS Barrow Cadbury Third Sector Research Centre. 